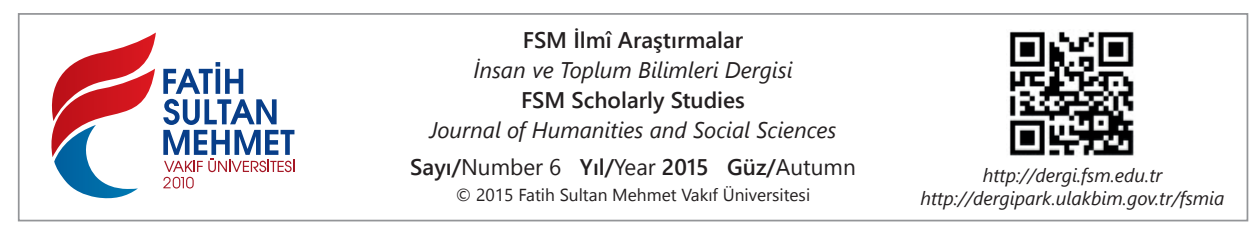

\title{
Yabancılara Arapça Öğretim Metotlarının Geliştirilmesi Sempozyumu: Uluslararası Sempozyum,
}

18-20 Aralık 2015, Fatih Sultan Mehmet Vakıf Üniversitesi, İstanbul

Bilindiği gibi uzun bir tarihe ve engin bir kültürel muhtevaya sahip olan Arap dili dünyada itibarı artan dillerden biri haline gelmiş bulunmaktadır. Nitekim bu dil 18 Aralık 1973 tarihinde Birleşmiş Milletler Genel Kurulunda 6. resmi çalışma dili olarak kabul edilmiştir. 2012 yılında ise UNESCO 18 Aralık gününü Dünya Arapça Günü olarak ilan etmiştir. Bu münasebetle Türkiye'de Arap Dili ile öğretime başlayan ilk Fakülte olma özelliğine sahip bulunan Fatih Sultan Mehmet Vakıf Üniversitesi İslâmî İlimler Fakültesinde; Arapça öğretiminin problemlerine çözüm üretmek ve Arapça öğretim programlarını geliştirmek amacıyla bu uluslararası sempozyum tertip edilmiştir.

Fatih Sultan Mehmet Vakıf Üniversitesi Îslâmi İlimler Fakültesi ve Lübnan'da bulunan Trablus Üniversitesi Îslâmi İlimler Fakültesi işbirliğiyle düzenlenen, "Yabancılara Arapça Öğretim Metotlarının Geliştirilmesi" adlı uluslararası sempozyum 18-20 Aralık 2015 tarihleri arasında Fatih Sultan Mehmet Vakıf Üniversitesi Topkapı Yerleşkesi konferans salonunda gerçekleştirilmiştir.

Genel olarak Sempozyumda hem konuların hem de davetlilerin seçiminde büyük bir titizlik gösterilmiş, özellikle de yabancılara Arapça öğretimi konusunda alanında birikim ve deneyimi olan yetkin bilim adamları toplantıya iştirak etmişlerdir.

Sempozyuma Türkiye dışında 10 ayrı ülkeden 18 bilim adamı ve araştırmacı bildiri sunmuştur.

Sempozyuma yabancılara Arapça öğretiminde önemli bir yeri olan şu üniversite ve araştırma merkezlerinden akademisyenler katılmıştır:

1- Alecso (Arap Bilim Kültür ve Eğitim Kurumu)

2- Trablus Üniversitesi- Lübnan

3- Kahire Üniversitesi- Misır

4- Midiyye Dr. Yahya Faris Üniversitesi - Cezayir 
5- Kasıd Arapça Eğitim Merkezi- Ürdün

6- Lisanü'l-ümm Dil Merkezi - Abu Dabi

7- El-Lisan Dil Merkezi - İsveç

8- Uluslararası Hartum Arapça Eğitim Enstitüsü- Sudan

9- Kahire, İstanbul ve Ürdün'de şubeleri bulunan Divan Dil Merkezi

10- Marmara Üniversitesi İlahiyat Fakültesi

11- İstanbul Üniversitesi İlahiyat Fakültesi

12- İstanbul Üniversitesi Edebiyat Fakültesi Doğu Dilleri Bölümü

13- Yalova Üniversitesi İlahiyat Fakültesi

14- Sakarya Üniversitesi İlahiyat Fakültesi

15- Sütçü İmam Üniversitesi İlahiyat Fakültesi

18 Aralık 2015 Cuma günü sempozyumun açılışında protokol konuşmaları sırasıyla Fatih Sultan Mehmet Vakıf Üniversitesi İslami İlimler Fakültesi Dekanı Prof. Dr. Ahmet Turan ARSLAN, Alecso (Arap Bilim Kültür ve Eğitim Kurumu) ve Mahedü'l-mahtûtâti'l-Arabiyye (Arapça Yazma Eserler Kurumu-Misır) müdürü Prof. Dr. Faysal el-Hafyan, Lübnan Trablus Üniversitesi Rektör Yardımcıs1 Prof. Dr. Rafet el-Mîkatî ve Fatih Sultan Mehmet Vakıf Üniversitesi Rektör Yardımcısı Prof. Dr. Ümit Doğay ARINÇ konuşma birer yaptılar.

Fatih Sultan Mehmet Vakıf Üniversitesi Îslâmi İlimler Fakültesi dekanı Prof. Dr. Ahmet Turan Arslan başkanlığında yapılan "İlim ve Konuşma Dili Olarak Arapça" başlıklı açılış oturumunda Kuveyt Üniversitesinden Prof. Dr. Hassan Tayyan "Arapça İfadelerin Özellikleri ve Güzelliği” isimli bildirisini, Lübnan Trablus Üniversitesi Îslâmi İlimler Fakültesi Dekanı Prof. Dr. Ali el-Bikâi ise "Îslâmi İlimler Açısından Arap Dilinin Önemi” konulu bildirisini sundu.

Sempozyumun ilk günü gerçekleştirilen "Arapça Öğretim Programlarının Geliştirilmesi: İç Yapı ve Dış Destek" konulu birinci oturuma Fatih Sultan Mehmet Vakıf Üniversitesi İslami İlimler Fakültesi dekan yardımcısı Prof. Dr. Ali BULUT başkanlık etmiştir. Bu oturumda Prof. Dr. Faysal el-HAYFÂN "Arapça Öğretim Programlarında Fikri ve Kültürel İçerikler: Değerlendirme ve Geliştirme” başlıklı bildirisini, Dr. Halid Ebû AMŞE “Arapça Öğretiminde Dil Bilimlerinin Kullanımı" isimli bildirisini, Prof. Dr. Halid Tanbûra el-HÜSEYNÎ “Arapça Öğretim Kütüphanesinin Geliştirilmesi” ve son olarak da Dr. Abdülbedî’ NEYRABÂNÎ “Arap Dilinin Temel Sözlüğü” isimli bildirilerini sunmuşlardır.

İkinci gün gerçekleştirilen "Dil Öğretiminde Tecrübelerin Geliştirilmesi” konulu oturuma Prof. Dr. Mehmet MAKSUDOĞLU başkanlık etmiştir. Bu oturumda Prof. Dr. Ali Abdullah Ahmed NAİM “Alecso’nun yayınladığ 1 El-Kitabü’ül Esasi: Değerlendirme ve Geliştirme", Doç. Dr. Adem YERİNDE "Dili Arapça Olmayanlara Arapça Öğretiminde Seviye Sisteminin Etkinliği”, Prof. Dr. Ab- 
durrahman ÖZDEMIR “Öğrenciler İçin Teşvikler ve Arapça'nın Dili Arapça Olmayanlara Öğretimindeki Etkisi” ve Muhammed ABS "Îslâmi İlimler Öğrencilerinin Okuma Becerisini Geliştirme: Örnek Olarak Merkezü'l-Lisâni'l-Ümmm Deneyimi" isimli bildirilerini sunmuşlardır.

"Öğrenci ve Öğretmen Arasında Becerileri Geliştirme" başlıklı üçüncü oturuma ise Prof. Dr. Abdullah KIZILCIK başkanlık etmiştir. Bu oturumda Prof. Dr. Ahmet BOSTANCI "Dili Arapça Olmayanlara Arapça Öğretiminde Ders Dış1 Etkinlikler", Prof. Dr. Mustafa URÂBÎ "Dili Arapça Olmayanlarda Konuşma Becerisini Geliştirme Üslupları”, Prof. Dr. Münir CUMA “Arapça Öğretiminde Unsurları ve Becerileri Birleştirme Sanatı" ve Mü'min el-ANNÂN “Dili Arapça Olmayanlara Arapça Öğretenin Yeterliliğì" isimli bildirilerini sunmuşlardır.

"Geliştirme ve Kalite Standartları" başlıklı dörsüncü oturuma Prof. Dr. Halil İbrahim Kaçar başkanlık etmiştir. Bu oturumda Dr. İslam YÜSRÎ "Dil Değerlendirmesinin Evrensel Kriterleri ve Bunların İslami İlimler Fakültelerinin Programlarında Uygulanması” ve Prof. Dr. Bulmeâlî en-NEZÎR “Arapça Öğretiminin Evrenselleştirilmesi" isimli bildirilerini sunmuşlardır.

Kapanış Oturumunda ise Fatih Sultan Mehmet Vakıf Üniversitesi Îslâmi İlimler Fakültesi Öğretim Üyesi Yrd. Doç. Dr. Mahmoud MISRİ, Prof. Dr. Rafet el-Mîkâtî ve Prof. Dr. Ahmet Turan ARSLAN birer değerlendirme ve teşekkür konuşması yapmışlardır.

Trablus Üniversitesi Rektör Yardımcısı Prof. Dr. Rafet el-MÎKÂTî konuşmasında sempozyumun hazırlanması ve tertip edilmesinde emeği geçen Fatih Sultan Mehmet Vakıf Üniversitesi Îslâmi İlimler Fakültesi Dekanı Prof. Dr. Ahmet Turan ARSLAN başta olmak üzere herkese ve Fatih Sultan Mehmet Vakıf Üniversitesi yöneticilerine teşekkürlerini sunmuş ve iki üniversite arasındaki işbirliğinin bundan sonra da devam etmesini dilemiştir.

Ardından Prof. Dr. Ahmet Turan ARSLAN hem teşekkürlerini hem de temenni ve dileklerini ifade etmiştir. Daha sonra iki üniversite temsilcileri karşılık11 hediyelerini sunmuşlardır. Akabinde de sempozyuma iştirak edenlere katılım belgeleri verilmiştir.

Ayrıca Sempozyumun ikinci ve üçüncü gününde Îslâmi İlimler Fakültesi Arapça Hazırlık sınıfında okutulan Silsiletü'l - Lisân isimli Arapça dil seti üzerine bir atölye çalışması gerçekleştirilmiştir.

$\mathrm{Bu}$ çalışmada ele alınan konular şunlardır:

Dil seviyelerinin gelişmesi.

Her seviyede kullanılacak güncel kelimeler ve ifade tarzları.

Öğrencinin dil becerilerinin (dinleme, okuma, yazma, konuşma ve anlama) gelişmesinde metin, diyalog ve alıştırmaların rolü. 
Üçüncü gün yapılan atölye çalışmasında ise Îslâmi İlimler Fakültesi Hazırlık Sınıfı öğretim elemanlarına öğretim metotları konusunda seminerler dizisi gerçekleştirilmiştir. Bu atölye çalışmalarına başka üniversite ve müesseselerden de Arapça öğretim görevlileri katılmışlardır.

Bu atölye çalışmalarında şu konular işlenmiştir:

Gazi Üniversitesi öğretim üyelerinde Prof. Dr. Mehmet Hakkı SUÇİN "Öğrenci Nasıl İlerler? Örnek Bir Ders Planı" konusunda, Fatih Sultan Mehmet Vakıf Üniversitesi İslami İlimler Fakültesi Arapça Hazırlık Okulu birim yöneticisi Abdülmunim SALAH "Öğretmenin Yeterlilikleri: Tarif ve Uygulama" ve Uluslararası Divan Dil Merkezi müdürü Dr. İslam YÜSRİ ise "Dil Becerilerini Ölçmeye Giriş" konulu atölye çalışmalarını sunmuşlardır. 